\title{
Kinetics of the Normal Folate Enterohepatic Cycle
}

\author{
Stephen E. Steinberg, Caryl L. Campbell, and Robert S. Hillman, Division \\ of Hematology, Department of Medicine, University of Washington Medical \\ School, Seattle, Washington 98195
}

\begin{abstract}
A B S T RAC T Detailed studies were undertaken to better define the role of the liver and the folate enterohepatic cycle in folate homeostasis. Three isotopes of folate were employed in a rat model to study several parameters: $(a)$ intestinal transport; $(b)$ variation in hepatic uptake after different routes of administration; (c) hepatic reduction, methylation, and polyglutamate formation; $(d)$ biliary excretion; $(e)$ transport of folate to tissue and its return to liver for re-entry into the enterohepatic cycle.
\end{abstract}

Folate absorption was not affected by the type of folate administered, but subsequent liver accumulation was greater when PteGlu ${ }_{1}$ was given rather than $\mathrm{CH}_{3} \mathrm{H}_{4} \mathrm{PteGlu}_{1}$. After liver uptake, $\mathrm{CH}_{3} \mathrm{H}_{4} \mathrm{PteGlu}_{1}$ is rapidly and quantitatively excreted into bile, whereas nonmethylated folates are either methylated and transported into bile or incorporated into a hepatic polyglutamate pool. Bile folate is then reabsorbed for distribution to both tissue and liver, completing the enterohepatic cycle. The importance of this cycle was demonstrated by long-term bile drainage and by transport studies with two isotopes of $\mathrm{CH}_{3} \mathrm{H}_{4} \mathrm{PteGlu}_{1}$. With bile drainage, serum folate levels fell to $30-40 \%$ of normal within $6 \mathrm{~h}$, a much more dramatic drop than that seen with folate-free diets alone. Studies with labeled $\mathrm{CH}_{3} \mathrm{H}_{4} \mathrm{PteGlu}_{1}$ demonstrated that about one-third was taken up by tissue, demethylated, and returned to liver for remethylation and recirculation through the bile and gut. This establishes the enterohepatic cycle as a major factor in folate homeostasis and, for the first time, demonstrates a transport pathway between tissue and liver for nonmethylated folate.

\section{INTRODUCTION}

Past studies of the kinetics of folate metabolism in man and animal models have used relatively large doses of unlabeled PteGlu ${ }_{1}$, or the isotopes of PteGlu ${ }_{1}$ and

Received for publication 19 June 1978 and in revised form 7 March 1979.
$\mathrm{CH}_{3} \mathrm{H}_{4}$ PteGlu ${ }_{1}$ to measure absorption, plasma clearance, and uptake of folate by tissues, especially the liver and kidney $(1-10)$. When various folate congeners are ingested, reduction and methylation to form $\mathrm{CH}_{3} \mathrm{H}_{4} \mathrm{PteGlu}_{1}$ are carried out during transport across the gut wall; the efficiency of gut methylation and clearance into tissue depending on the dose administered (11-14). Intravenous injection of isotopic folate is followed by immediate clearance into the intracellular space; rapid reduction and methylation to form $\mathrm{CH}_{3} \mathrm{H}_{4}$ $\mathrm{PteGlu}_{1}$; and a more gradual labeling of one or more intracellular polyglutamate pools $(5,7,10,15-18)$. Again, the apparent rates of clearance, methylation, and pool labeling vary according to the dose of folate administered and the state of folate nutrition $(10,19)$. As yet, measurements of the turnover of tissue mono- and polyglutamate folate pools and the exchange of folates between tissues have not been carried out in any systematic fashion. Cooper and coworkers $(20,21)$ reported clearance into bile of isotopic folate, which they presumed was destined for reabsorption by the gut. Work by Hillman et al. (19) would suggest a role for a folate enterohepatic cycle in folate homeostasis, inasmuch as alcohol appears to reduce the level of serum folate and tissue folate supply by interfering with folate clearance into bile (19).

To examine the kinetics of the folate enterohepatic cycle and transport between tissues, the present study has employed three different isotopes of folate in a well-defined animal model. Several aspects were investigated: gut transport; liver uptake as a function of the route of administration; intrahepatic reduction, methylation, and polyglutamate formation; biliary excretion; recirculation through the enterohepatic cycle; and the turnover of folate congeners in tissue and the subsequent transport of folate back to the liver from tissue for re-entry into the enterohepatic cycle. This work has demonstrated the important role of the enterohepatic cycle in normal folate homeostasis and for the first time has provided evidence for the transport of folate from tissue back to liver. 


\section{METHODS}

Kinetics of the folate enterohepatic cycle were studied in 150-250-g female Sprague-Dawley rats, with three isotopes of folate: $\left[{ }^{3} \mathrm{H}\right] \mathrm{PteGlu}_{1},\left[{ }^{14} \mathrm{CH}_{3}\right] \mathrm{H}_{4} \mathrm{PteGlu}_{1}$, and $\mathrm{CH}_{3} \mathrm{H}_{4}\left[{ }^{3} \mathrm{H}\right] \mathrm{PteGlu}$. The $\left[{ }^{3} \mathrm{H}\right] \mathrm{PteGlu}_{1}$ was obtained from Amersham Corp. (Arlington Heights, Ill.) as PteGlu ${ }_{1}$ labeled on the $3^{\prime}, 5^{\prime}$ (phenyl group) $9^{\prime}$ positions, with a $20-45 \mathrm{Ci} / \mathrm{mmol}$ spc act. The isotope was reconstituted with normal saline and stored at $-40^{\circ} \mathrm{C}$ in aliquots of $10 \mu \mathrm{Ci}$. Chromatography of standards taken from the individual tubes at the time of study demonstrated an initial purity of $90-95 \%$ with a deterioration of $<2 \% /$ mo. $\left[{ }^{14} \mathrm{CH}_{3}\right] \mathrm{H}_{4}$ PteGlu $\mathrm{u}_{1}$, obtained from Amersham Corp. with a spc act of $\cong 53 \mathrm{mCi} / \mathrm{mmol}$, demonstrated better than $95 \%$ purity and deteriorated at a rate of $<1 \% / \mathrm{mo}$ when stored at $-40^{\circ} \mathrm{C}$ in $1 \%$ ascorbate.

$\left.\mathrm{CH}_{3} \mathrm{H}_{4}{ }^{3} \mathrm{H}\right]$ PteGlu ${ }_{1}$ was prepared in normal rats by injection of $\left[{ }^{3} \mathrm{H}\right] \mathrm{PteGlu}$. Bile was collected for $4 \mathrm{~h}$ into iced tubes containing 2-mercaptoethanol. An aliquot of the collection was chromatographed and the folate content measured with Lactobacillus casei. For enteric studies, only bile in which $85 \%$ or more of the label chromatographed as $\mathrm{CH}_{3} \mathrm{H}_{4} \mathrm{PteGlu}_{1}$ was used. Folate content of this bile was $1.5-2.5 \mu \mathrm{g} / \mathrm{ml}$. For intravenous studies of $\mathrm{CH}_{3} \mathrm{H}_{4}\left[{ }^{3} \mathrm{H}\right] \mathrm{PteGlu}_{1}$ clearance, pooled bile was chromatographed on Sephadex G-15 (Pharmacia Fine Chemicals, Piscataway, N. J.) with $0.1 \%$ ascorbate, the appropriate volumes lyophilized to dryness, and the $\mathrm{CH}_{3} \mathrm{H}_{4}$ $\left[{ }^{3} \mathrm{H}\right] \mathrm{PteGlu}_{1}$ resuspended in sterile saline that contained $0.1 \%$ ascorbate. As determined by $L$. case $i$, the specific activity of this purified product was $\cong 20 \mathrm{mCi} / \mathrm{mmol}$ with 90 $95 \%$ of the label cochromatographing with a $\left[{ }^{14} \mathrm{CH}_{3}\right] \mathrm{H}_{4} \mathrm{PteGlu}_{1}$ marker (Fig. 1).

The various parameters of folate uptake and distribution were studied according to the following protocols:

Liver uptake. The immediate clearance of folate isotopes into liver was measured after a bolus injection into the right heart or portal vein. Animals were anesthetized with pentobarbitol sodium and either the portal vein or external jugular vein isolated. In paired studies, $5 \mu \mathrm{Ci}(90-100 \mathrm{ng})$ of $\left[{ }^{3} \mathrm{H}\right]-$ PteGlu $_{1}$ or $0.01 \mu \mathrm{Ci}(<200 \mathrm{ng})$ of $\left[{ }^{14} \mathrm{CH}_{3}\right] \mathrm{H}_{4} \mathrm{PteGlu}_{1}$ was injected in a diluent volume of $<0.2 \mathrm{ml}$. At exactly $3 \mathrm{~min}$, the liver was flushed with ice-cold $1 \%$ ascorbate-isotonic saline via the portal system. At this time plasma clearance of isotope was virtually complete, but label was not yet detectable in the bile. Liver and kidneys were then removed, weighed, and immediately homogenized in $20-30 \mathrm{ml}$ of $1 \%$ ascorbate in phosphate buffer, pH 6.0. Homogenates were boiled for 7 min and autoclaved at $110^{\circ} \mathrm{C}$ for $10 \mathrm{~min}$ to precipitate remaining protein. $1 \mathrm{ml}$ of the supernate was pipetted into Aquasol (American Cyanamid Co., Bound Brook, N. J.) for counting in a Packard liquid scintillation counter (Packard

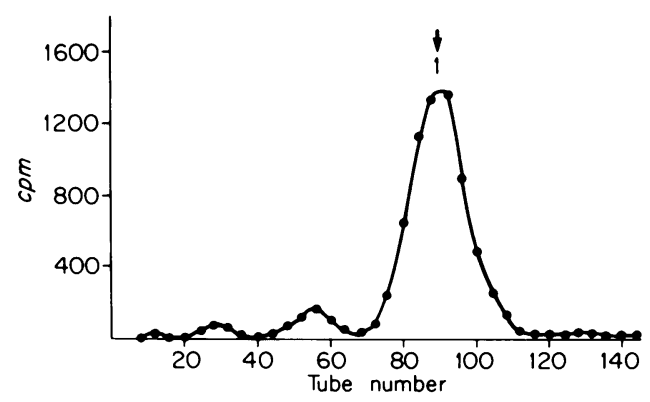

FIGURE 1 DEAE-A-25 chromatography of purified rat bile. $\left[{ }^{14} \mathrm{CH}_{3}\right] \mathrm{H}_{4} \mathrm{PteGlu}_{1}$ marker eluted at tube numbers 80-100 (1).
Instrument Co., Inc., Downers Grove, Ill.). Correction for quenching was made with the external automatic standard method.

Gut absorption, liver uptake, and excretion into bile. The percent uptake of isotope by the liver and the subsequent rate of appearance of the label in bile was studied in a second group of rats. Animals were anesthetized with pentobarbitol sodium, the abdominal wall incised, and the bile duct isolated and cannulated with a 0.038 -inch polyethylene catheter. A 13-cm segment of jejunum was isolated and both ends cannulated with polyethylene tubing. The isolated loop was then gently washed with warm saline until the return was clear. As soon as bile flow had stabilized at about $1 \mathrm{ml} / \mathrm{h}$, the distal end of the gut loop was clamped and $1 \mathrm{ml}$ of test solution: $5 \mu \mathrm{Ci}(100 \mu \mathrm{g})\left[{ }^{3} \mathrm{H}\right] \mathrm{PteGlu}_{1}, 1 \mu \mathrm{Ci}(10 \mu \mathrm{g})\left[{ }^{14} \mathrm{CH}_{3}\right] \mathrm{H}_{4} \mathrm{PteGlu}_{1}$, or bile that contained $\cong 2 \mu \mathrm{g} \mathrm{L}$. case $i$-active folate with 0.05 $\mu \mathrm{Ci} \mathrm{CH}_{3} \mathrm{H}_{4}\left[{ }^{3} \mathrm{H}\right] \mathrm{PteGlu}{ }_{1}$, was injected. After $\mathrm{l} \mathrm{h}$ the loop was unclamped and flushed with warm saline. By this time, $90 \%$ of the isotope had been absorbed. All wash returns were collected for counting and chromatography. To investigate the timing of gut absorption, a second group of animals was studied after intravenous injection of the same isotopes. Biliary excretion of folate isotopes was monitored by collecting serial samples of bile at 5-min intervals for immediate dilution in Aquasol for counting, and 1-h aliquots of bile in 2-mercaptoethanol for chromatography. Animals were sacrificed at either $1,2,3,6$, or $12 \mathrm{~h}$, the liver flushed through the portal system, removed, and processed as described above for counting and chromatography.

All chromatography of tissue extracts was carried out on $0.9 \times 120-\mathrm{cm}$ columns of Sephadex G-15-120 and eluted with $0.1 \mathrm{M}$ potassium phosphate buffer, $\mathrm{pH} 7.0$, that contained $2 \mathrm{mM} 2$-mercaptoethanol. The effluent was collected in 1.6$\mathrm{ml}$ fractions at a flow-rate of $15 \mathrm{ml} / \mathrm{h}$ and $1 \mathrm{ml}$ of each fraction pipetted into Aquasol for counting. To specifically identify $\mathrm{CH}_{3} \mathrm{H}_{4} \mathrm{PteGlu}_{1}$, an aliquot of eluate volumes $125-150 \mathrm{ml}$ was placed on a $1.5 \times 30-\mathrm{cm}$ column of DEAE (A-25) Sephadex. A linear gradient of $0.1-1.0 \mathrm{M}$ potassium phosphate buffer, pH 6.0, containing $2 \mathrm{mM} 2$-mercaptoethanol was used for elution. Labeled PteGlu $\mathrm{CH}_{3} \mathrm{H}_{4} \mathrm{PteGlu}_{1}$ and $p$-aminobenzoylglutamate were employed as markers in selected chromatographs. Peak elutions of $\mathrm{CH}_{3} \mathrm{H}_{4} \mathrm{PteGlu}{ }_{1}$ occurred at tube numbers 90-100, whereas PteGlu ${ }_{1}$ eluted at tube numbers $120-130(10)$.

Total liver uptake was calculated as the sum of the liver counts and total counts excreted in the bile. Percentage of liver uptake was expressed either as the percentage of input (total counts injected or absorbed from the gut) or as the percentage of total liver uptake. Bile excretion was expressed either as the percentage of input, or as the percentage of total liver uptake. All statistical analysis was by the Student's $t$ test.

Long-term bile drainage. A third group of animals had their bile ducts cannulated as described above and a polyethylene catheter placed in the right atrium for serial measurements of plasma folate. Both cannulae were tunneled through the subcutaneous tissue to exit at a position just behind the head. The catheters were stabilized in a manner so as to allow normal activity during sampling. Such animals were then maintained for periods of up to $72 \mathrm{~h}$ on one of two folate-deficient diets: a liquid diet of $25 \%$ sucrose in water with added succinylsulfathiazole or a commercially prepared low-folate diet. During this time both the serum folate and bile folate levels were measured twice daily by the aseptic L. casei method of Herbert (22).

Tissue supply and return to the liver. A fourth group of animals was prepared in a fashion identical to that used to study gut absorption, liver uptake, and biliary excretion. As 
soon as bile flow had stabilized, a test solution of bile that contained either $\mathrm{CH}_{3} \mathrm{H}_{4}\left[{ }^{3} \mathrm{H}\right] \mathrm{PteGlu}$ or $\left[{ }^{14} \mathrm{CH}_{3}\right] \mathrm{H}_{4} \mathrm{PteGlu}_{1}$ was placed in the isolated gut loop. Bile was collected continuously for $4 \mathrm{~h}$, after which the animals were sacrificed. Chromatographic studies of the liver, kidney, and bile folates were performed as above. Comparison of the quantity of each isotope appearing in bile was used to provide an indirect measure of the rate of return and the character of the folate transported from tissue back to liver. Inasmuch as the $\mathrm{CH}_{3}$ group of $\mathrm{CH}_{3} \mathrm{H}_{4} \mathrm{PteGlu}_{1}$ rapidly enters a large tissue methionine pool, any excess of the ${ }^{3} \mathrm{H}$-labeled isotope over ${ }^{14} \mathrm{C}$-labeled congeners appearing in bile should reflect the transport of nonmethylated folate from tissue to liver.

\section{RESULTS}

Studies of the clearance of folate isotopes after intravenous administration demonstrated differences in percent uptake by liver and kidney according to both the type of folate used and the site of injection (Table I). Whereas uptake of $\left[{ }^{3} \mathrm{H}\right] \mathrm{PteGlu}_{1}$ was not influenced by the site of intravenous injection, liver uptake of $\left[{ }^{14} \mathrm{CH}_{3}\right] \mathrm{H}_{4} \mathrm{PteGlu}_{1}$ was higher after portal vein injection than after right heart injection $(P<0.01)$. When the two isotopes were compared, liver uptake of $\left[{ }^{3} \mathrm{H}\right] \mathrm{PteGlu}_{1}$ was slightly higher than for $\left[{ }^{14} \mathrm{CH}_{3}\right] \mathrm{H}_{4} \mathrm{PteGlu}_{1}(P$ $<0.025)$.

The route of administration had a significant effect on hepatic uptake of both isotopes (Table II). The percentage of $\left[{ }^{3} \mathrm{H}\right] \mathrm{PteGlu}_{1}$ appearing in liver and bile in $1 \mathrm{~h}$ was nearly twice as high after gut loop administration as after right heart injection $(P<0.001)$. A similar difference was observed after administration of $\left[{ }^{14} \mathrm{CH}_{3}\right] \mathrm{H}_{4}$ PteGlu $_{1}(P<0.001)$. When the two isotopes were compared, the combined liver and bile accumulation of label was significantly greater after $\left[{ }^{3} \mathrm{H}\right] \mathrm{PteGlu}_{1}$ administration, regardless of the route $(P<0.005$ for right heart injection and $P<0.001$ for gut loop administration). This difference is almost entirely accounted for by the increased hepatic retention of $\left[{ }^{3} \mathrm{H}\right] \mathrm{PteGlu}_{1}$ over $\left[{ }^{14} \mathrm{CH}_{3}\right] \mathrm{H}_{4} \mathrm{PteGlu}_{1}(P<0.001)$ (Table II).

The rate of appearance of isotopic folates in bile was studied by serial sampling of bile for up to $2 \mathrm{~h}$ after administration (Fig. 2). Bile clearance varied both for the type of folate isotope and the route of administration. As shown in Fig. 2B, intravenous injection of $\left[{ }^{14} \mathrm{CH}_{3}\right] \mathrm{H}_{4^{-}}$ PteGlu $_{1}$ resulted in an immediate appearance of labeled material in bile, similar to that observed after injection of rose bengal (not shown) and peaking at 10

TABLE I

Percent Uptake of Intravenous Isotope at $3 \mathrm{Min}$

\begin{tabular}{lrrrrr}
\hline & \multicolumn{2}{c}{ Liver } & & \multicolumn{2}{c}{ Kidney } \\
\cline { 2 - 3 } & Right heart & Portal & & Right heart & Portal \\
\hline$\left[{ }^{3} \mathrm{H}_{\text {PteGlu }}\right.$ & $10.4 \pm 1.9$ & $12.5 \pm 2.7$ & & $11.6 \pm 1.1$ & $11.1 \pm 1.8$ \\
{$\left[{ }^{14} \mathrm{CH}_{3}\right] \mathrm{H}_{4}$ PteGlu $_{1}$} & $7.8 \pm 1.2$ & $10.2 \pm 0.4$ & & $13.6 \pm 2.9$ & $13.4 \pm 3.3$ \\
\hline
\end{tabular}

TABLE II

Percent Distribution of Isotope in $1 h^{*}$

\begin{tabular}{lrr}
\hline & Right heart & \multicolumn{1}{c}{ Gut } \\
\hline$\left[{ }^{3} \mathrm{H}\right]$ PteGlu & & \\
$\quad$ Liver & & \\
Bile & $8.58 \pm 1.43$ & $11.90 \pm 2.88$ \\
Total & $4.40 \pm 1.24$ & $12.95 \pm 2.88$ \\
& $12.98 \pm 1.27$ & $25.06 \pm 4.59$ \\
{$\left[{ }^{14} \mathrm{CH}_{3}\right] \mathrm{H}_{4} \mathrm{PteGlu}_{1}$} & & \\
Liver & $2.11 \pm 0.53$ & $2.43 \pm 0.40$ \\
Bile & $6.47 \pm 1.80$ & $11.95 \pm 2.78$ \\
Total & $8.58 \pm 2.19$ & $14.38 \pm 2.97$ \\
\hline
\end{tabular}

* Expressed as counts in liver or bile divided by total counts injected intravenously or absorbed by the gut.

$\min$ (slope $=0.0543 \pm 0.016$ ). In contrast, the peak excretion of $\left[{ }^{3} \mathrm{H}\right] \mathrm{PteGlu}_{1}$ (Fig. 2A), as $\mathrm{CH}_{3} \mathrm{H}_{4}\left[{ }^{3} \mathrm{H}\right] \mathrm{PteGlu}$, was delayed by 5-6 $\mathrm{min}$ and the subsequent clearance rate was slower (slope $=0.0152 \pm 0.0098 ; P<0.001$ ).

After gut administration of the isotopes, the rate of appearance in bile was almost identical; $\left[{ }^{14} \mathrm{CH}_{3}\right] \mathrm{H}_{4}$ $\mathrm{PteGlu}_{1}$ first appeared in bile at about 12-13 min, whereas $\mathrm{CH}_{3} \mathrm{H}_{4}\left[{ }^{3} \mathrm{H}\right] \mathrm{PteGlu}$ began to be cleared at 15 min. Subsequent clearance rates were virtually identical (Fig. 2C).

Measurements of liver activity and bile clearance after intravenous injection demonstrated a different pattern of clearance between the two isotopes (Fig. 3). Of the total liver uptake of $\left[{ }^{14} \mathrm{CH}_{3}\right] \mathrm{H}_{4} \mathrm{PteGlu}_{1}$ (i.e., counts retained by liver plus counts excreted into bile) at $6 \mathrm{hr}, 97 \%$ were cleared into the bile and $2-3 \%$ remained in the liver, whereas $73 \%$ of $\left[{ }^{3} \mathrm{H}\right] \mathrm{PteGlu}_{1}$ activity was cleared into bile and $15 \%$ remained in the liver $(\mathrm{P}<0.001)$. Chromatographic studies of bile and liver at $1,3,6$, and $12 \mathrm{~h}$ demonstrated that with $\left[{ }^{3} \mathrm{H}\right]-$ PteGlu $_{1}, 60-90 \%$ of bile activity cochromatographed

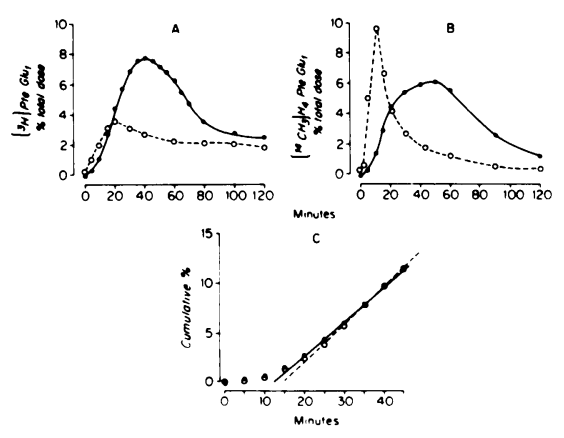

Figure 2 Clearance of isotope into bile after intravenous (O) or gut (O) administration is shown for $\left[{ }^{3} \mathrm{H}\right] \mathrm{PteGlu}_{1}(\mathrm{~A})$ and $\left[{ }^{14} \mathrm{CH}_{3}\right] \mathrm{H}_{4} \mathrm{PteGlu}_{1}(\mathrm{~B})$. The total label accumulated in bile over time after gut administration $(\mathrm{C})$ is shown for $\left[{ }^{3} \mathrm{H}\right] \mathrm{PteGlu}_{1}$ (○), and $\left[{ }^{14} \mathrm{CH}_{3}\right] \mathrm{H}_{4}$ PteGlu $_{1}(\mathbf{O})$. 


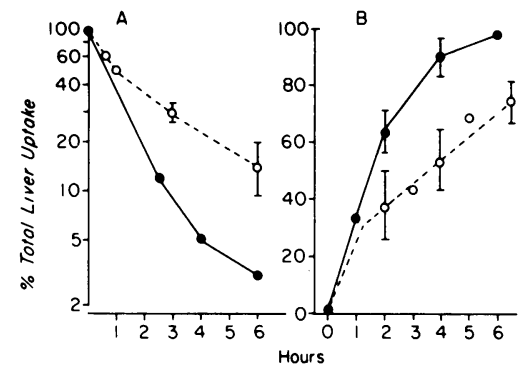

Figure 3 The amount of isotope remaining in the liver (A) and accumulating in the bile output (B) expressed as a percentage of the total liver uptake (i.e., the amount remaining in liver plus the amount excreted in bile) is shown for $\left[{ }^{3} \mathrm{H}\right]-$ PteGlu ${ }_{1}(\mathrm{O})$ and $\left[{ }^{14} \mathrm{CH}_{3}\right] \mathrm{H}_{4} \mathrm{PteGlu}_{1}(\mathbf{O})$.

with a $\mathrm{CH}_{3} \mathrm{H}_{4} \mathrm{PteGlu}_{1}$ peak, with $10-40 \%$ in positions compatible with $\mathrm{CHOH}_{4} \mathrm{PteGlu}_{1}$ and 4- $\alpha$-hydroxy-5methyl $\mathrm{H}_{4} \mathrm{PteGlu}_{1}$ (not shown), whereas virtually $100 \%$ of bile counts from $\left[{ }^{14} \mathrm{CH}_{3}\right] \mathrm{H}_{4} \mathrm{PteGlu}_{1}$-treated animals were $\mathrm{CH}_{3} \mathrm{H}_{4} \mathrm{PteGlu}_{1}$. At the same time, residual liver activity after $\left[{ }^{3} \mathrm{H}\right] \mathrm{PteGlu}_{1}$ was associated with an increasing $\mathrm{CH}_{3} \mathrm{H}_{4} \mathrm{PteGlu}_{5}$ peak, (Fig. 4). By $6-12 \mathrm{~h}$, $<20 \%$ of the label was still present as either $\left[{ }^{3} \mathrm{H}\right]-$ $\mathrm{PteGlu}_{1}, \mathrm{CH}_{3} \mathrm{H}_{4}\left[{ }^{3} \mathrm{H}\right] \mathrm{PteGlu}_{1-3}$, or breakdown products. The small residual activity after $\left[{ }^{14} \mathrm{CH}_{3}\right] \mathrm{H}_{4} \mathrm{PteGlu}_{1}$ was $>95 \% \mathrm{CH}_{3} \mathrm{H}_{4}$ PteGlu $_{1}$.

The results of long-term bile drainage studies are shown in Fig. 5. A rapid fall in serum folate levels to $30 \%$ of base line was observed within $4-6 \mathrm{~h}$ of initiation of bile drainage. A further, more gradual reduction continued over the next 48-72 h. Serum folate levels were normalized if bile was reinstilled in the gut.

The fate of $\mathrm{CH}_{3} \mathrm{H}_{4} \mathrm{PteGlu}_{1}$ after gut reabsorption was studied, with test solutions of bile containing $\left[{ }^{14} \mathrm{CH}_{3}\right]-$ $\mathrm{H}_{4}$ PteGlu ${ }_{1}$ and(or) $\mathrm{CH}_{3} \mathrm{H}_{4}\left[{ }^{3} \mathrm{H}\right] \mathrm{PteGlu}_{1}$. As shown in Fig. 6 , a total of $26 \pm 6 \%$ of the $\left[{ }^{14} \mathrm{CH}_{3}\right] \mathrm{H}_{4} \mathrm{PteGlu}_{1}$ subsequently appeared in bile over a 4 -h period. In contrast,

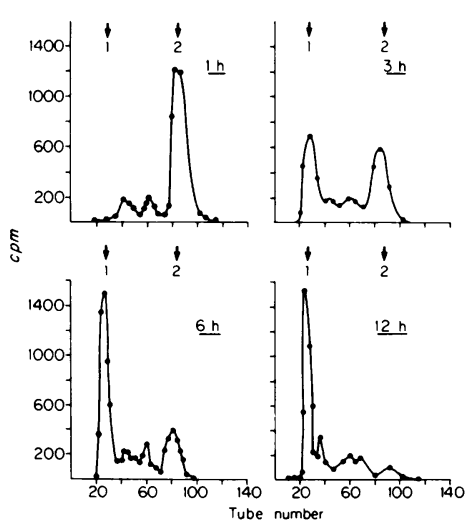

Figure 4 Sephadex G-15 chromatography of rat livers removed at $1,3,6$, and $12 \mathrm{~h}$ are shown. Pentaglutamate marker eluted at tube numbers 28-38 (1) and monoglutamate marker eluted at tube numbers 85-95 (2).

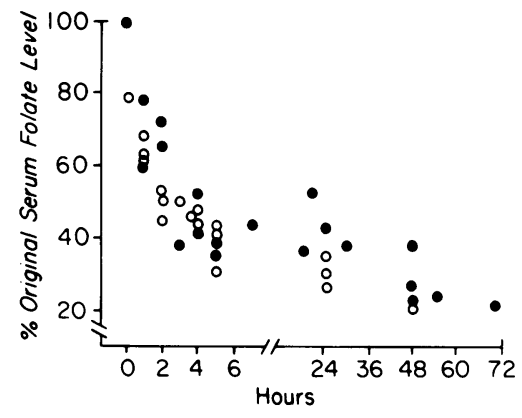

Figure 5 The rate of reduction of serum folate levels during continuous bile drainage is shown for animals maintained on two folate-free diets: a liquid diet of $25 \%$ sucrose in water with added sulpha $(\bigcirc)$ and a commercially prepared low-folate diet (O).

$47 \pm 5 \%$ of the $\mathrm{CH}_{3} \mathrm{H}_{4}\left[{ }^{3} \mathrm{H}\right] \mathrm{PteGlu}$ label appeared in bile during the 4-h study period with another $3-9 \%$ detectable in liver at the end of $4 \mathrm{~h}$. Therefore, as much as one-third of the folate taken up by tissue was returned to the liver after removal of the methyl group. By $4 \mathrm{~h}$, $32 \%$ of the ${ }^{3} \mathrm{H}$ label, which returned to the liver but was not excreted into bile, was incorporated into the liver $\mathrm{CH}_{3} \mathrm{H}_{4} \mathrm{PteGlu}_{5}$ pool. This incorporation requires nonmethylated folate as substrate.

\section{DISCUSSION}

These studies have further defined the major role that the enterohepatic pathway plays in folate homeostasis, by clarifying the kinetics of the reabsorption and biliary clearance of folate congeners. When small amounts of $\left[{ }^{3} \mathrm{H}\right] \mathrm{PteGlu}_{1}$ and $\left[{ }^{14} \mathrm{CH}_{3}\right] \mathrm{H}_{4} \mathrm{PteGlu}_{1}$ were placed in the jejunum, they were rapidly absorbed, transported to the liver, and cleared into bile, predominantly as $\mathrm{CH}_{3} \mathrm{H}_{4} \mathrm{PteGlu}_{1}$. $\left[{ }^{14} \mathrm{CH}_{4}\right] \mathrm{PteGlu}_{1}$ appeared in bile unchanged as early as $10 \mathrm{~min}$ after gut

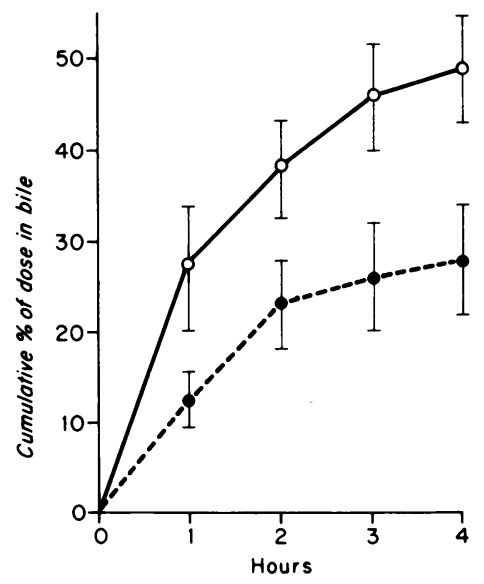

Figure 6 The percentage of the enterically administered dose accumulating in bile over $4 \mathrm{~h}$ is shown for $\mathrm{CH}_{3} \mathrm{H}_{4}\left[{ }^{3} \mathrm{H}\right]$ $\mathrm{PteGlu}_{1}(\mathrm{O})$ and $\left[{ }^{14} \mathrm{CH}_{3}\right] \mathrm{H}_{4} \mathrm{PteGlu}_{1}(\bullet)$. 
administration, whereas $\left[{ }^{3} \mathrm{H}\right] \mathrm{PteGlu} \mathrm{u}_{1}$ appeared in bile after conversion to $\mathrm{CH}_{3} \mathrm{H}_{4}\left[{ }^{3} \mathrm{H}\right] \mathrm{PteGlu}_{1}$ in a similar time period. Therefore, the time required for reduction and methylation of PteGlu $\mathbf{u}_{1}$ by gut mucosal and(or) liver parenchymal cells is negligible when compared to the time required for transport.

When given intravenously, $\left[{ }^{14} \mathrm{CH}_{3}\right] \mathrm{H}_{4} \mathrm{PteGlu}_{1}$ was cleared into bile as rapidly as rose bengal, confirming results of Lavoie and Cooper (21). Although the first appearance of $\left[{ }^{3} \mathrm{H}\right] \mathrm{PteGlu}_{1}$ in bile as $\mathrm{CH}_{3} \mathrm{H}_{4}\left[{ }^{3} \mathrm{H}\right] \mathrm{Pte}$ $\mathrm{Glu}_{1}$ was also immediate, the subsequent rate of clearance of $\left.\mathrm{CH}_{3} \mathrm{H}_{4}{ }^{3} \mathrm{H}\right] \mathrm{PteGlu}_{1}$ was slower and the peak of excretion was delayed. These kinetics could be explained by the time required for a saturable system to reduce and methylate $\left[{ }^{3} \mathrm{H}\right] \mathrm{PteGlu}_{1}$. An alternative explanation, the presence of a constant hepatic pool of PteGlu ${ }_{1}$, was ruled out by chromatographic studies of liver folate after $\left[{ }^{3} \mathrm{H}\right] \mathrm{PteGlu} \mathrm{u}_{1}$ administration. This and other studies have shown that most of the label was either converted to $\mathrm{CH}_{3} \mathrm{H}_{4} \mathrm{PteGlu}_{5}$, or had been cleared into bile as $\mathrm{CH}_{3} \mathrm{H}_{4} \mathrm{PteGlu}_{1}(15-18,23,24)$.

The total hepatic uptake is influenced both by the type of folate and the route of administration. After gut instillation, a greater percentage of $\left[{ }^{3} \mathrm{H}\right] \mathrm{PteGlu}_{1}$ was cleared into the liver and bile within the 1 st $\mathrm{h}$ than of $\left[{ }^{14} \mathrm{CH}_{3}\right] \mathrm{H}_{4}$ PteGlu $\mathrm{u}_{1}$. This could not be explained by a difference in absorption, because gut uptake was better than $90 \%$ for both isotopes. One explanation might be the presence of a plasma binder that preferentially binds PteGlu $\mathrm{u}_{1}$, and transports it to the liver (25). A second comes from the previous observation of independent transport mechanisms for $\mathrm{CH}_{3} \mathrm{H}_{4} \mathrm{PteGlu}_{1}$ and PteGlu across cell membranes (26). This would make it possible for an increased clearance into liver of the $\left[{ }^{3} \mathrm{H}\right] \mathrm{PteGlu}{ }_{1}$, inasmuch as gut methylation would provide both $\left[{ }^{3} \mathrm{H}\right] \mathrm{PteGlu}_{1}$ and $\mathrm{CH}_{3} \mathrm{H}_{4}\left[{ }^{3} \mathrm{H}\right] \mathrm{PteGlu}$ for transport to the liver. The difference could also reflect a greater avidity of peripheral tissue for $\mathrm{CH}_{3} \mathrm{H}_{4} \mathrm{PteGlu}_{1}$, a possibility that was in fact supported by the observation of a slightly reduced uptake of $\left[{ }^{14} \mathrm{CH}_{3}\right] \mathrm{H}_{4} \mathrm{PteGlu}_{1}$ into liver after right heart injection. Finally, removal of the ${ }^{14} \mathrm{CH}_{3}$ group from the $\left[{ }^{14} \mathrm{CH}_{3}\right] \mathrm{H}_{4} \mathrm{PteGlu}_{1}$ by tissue could prevent recirculation and thereby reduce the amount accumulated by liver.

Once taken up by liver, the fate of the two forms of folate was quite different. $\left[{ }^{14} \mathrm{CH}_{3}\right] \mathrm{H}_{4} \mathrm{PteGlu}_{1}$ was rapidly and quantitatively cleared into bile, so that $<3 \%$ of the isotope was still in the liver at $6 \mathrm{~h}$. Moreover, there was no labeling of the polyglutamate pool. In contrast, $15-20 \%$ of the $\left[{ }^{3} \mathrm{H}\right] \mathrm{PteGlu}_{1}$ was still present in liver at $6 \mathrm{~h}$, predominately in the form of polyglutamate. This provides in vivo confirmation of previous data showing that the principle substrate for polyglutamate formation is not $\mathrm{CH}_{3} \mathrm{H}_{4} \mathrm{PteGlu}_{1}$ but some other nonmethylated form of folate, perhaps $\mathrm{H}_{2}$ or $\mathbf{H}_{4} \mathrm{PteGlu}_{1}$ (27-30). The observation also establishes a need for the liver to obtain nonmethylated folates to maintain the intracellular polyglutamate folate pool. Because the $\left[{ }^{14} \mathrm{CH}_{3}\right] \mathrm{H}_{4} \mathrm{PteGlu}_{1}$ taken up by the liver was completely cleared in as little as $4-6 \mathrm{~h}$ without labeling a liver protein or intracellular methionine pool (even at $3 \mathrm{~min}$ ), it would appear that the liver does not convert large amounts of $\mathrm{CH}_{3} \mathrm{H}_{4} \mathrm{PteGlu}_{1}$ to the nonmethylated folate required for polyglutamate formation. Instead, a transport pathway must exist for the supply of nonmethylated folate to hepatic parenchymal cells. Moreover, the rapidity of the clearance of $\mathrm{CH}_{3} \mathrm{H}_{4}$ PteGlu ${ }_{1}$ into bile again demonstrates the importance of the enterohepatic cycle in normal folate homeostasis. This was confirmed by measurements of serum folate levels during bile drainage, which lowered serum folate levels much more rapidly than did dietary deficiency (24).

After the intravenous administration of either isotope, at least $90 \%$ of the label was cleared within $3 \mathrm{~min}$, into tissues other than the liver (Table I). Chromatography at this time showed that all of the label in the liver was associated wth the original isotope. Onehalf of the label administered as $\mathrm{CH}_{3} \mathrm{H}_{4}\left[{ }^{3} \mathrm{H}\right] \mathrm{PteGlu}$ returned to the liver within $4 \mathrm{~h}$ in a form suitable for incorporation into polyglutamate. In contrast, the amount of additional $\left[{ }^{14} \mathrm{CH}_{3}\right] \mathrm{H}_{4} \mathrm{PteGlu}_{1}$ recovered by the liver at $1 \mathrm{~h}$ was $<1 \%$ (Table II). Although the liver probably utilizes some $\mathrm{CH}_{3} \mathrm{H}_{4} \mathrm{PteGlu}_{1}$ in the formation of methionine, the fact that all of the initial hepatic counts could be identified as $\left[{ }^{14} \mathrm{CH}_{3}\right] \mathrm{H}_{4} \mathrm{PteGlu}_{1}$, and that hepatic losses over the next hour could be entirely accounted for by $\left[{ }^{14} \mathrm{CH}_{3}\right] \mathrm{H}_{4} \mathrm{PteGlu}_{1}$ excretion into the bile (Table I and II), demonstrate that this is not quantitatively important. Because less of the label returned from $\left[{ }^{14} \mathrm{CH}_{3}\right] \mathrm{H}_{4} \mathrm{PteGlu}_{1}$ than from $\mathrm{CH}_{3} \mathrm{H}_{4}\left[{ }^{3} \mathrm{H}\right] \mathrm{PteGlu}_{1}$, and the returning folate was a suitable substrate for polyglutamate formation, the folate congener must have been nonmethylated (31-34).

The presence of such a pathway is consistent with previous observations of liver folate kinetics. In animals maintained on a folate-deficient diet, McGuffin et al. (31), have shown that there is a parallel reduction in liver and plasma folate levels compatible with a transport pathway between liver and tissue. The kinetics of folate in vitamin $B_{12}$ deficiency also conform to this model (32-34). Patients with $B_{12}$ deficiency have been shown to have decreased hepatic folate levels often accompanied by elevated serum levels of $\mathrm{CH}_{3} \mathrm{H}_{4}$ PteGlu ${ }_{1}$. The so-called "methyl trap" hypothesis provides that intracellular folates are decreased because of an inability to demethylate $\mathrm{CH}_{3} \mathrm{H}_{4} \mathrm{PteGlu}_{1}$ in the absence of $B_{12}$. Less nonmethylated folate would be available for transport back to the liver, resulting in decreased hepatic folate levels, while serum $\mathrm{CH}_{3} \mathrm{H}_{4}$ -

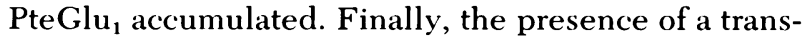
port pathway from tissue to liver for a folate that is nonmethylated and, in addition, incompletely reduced would help explain the high concentration of dihydro- 
folate reductase found in liver, in spite of its relatively low level of cellular proliferation $(35,36)$.

\section{ACKNOWLEDGMENT}

This work was supported by U.S. Public Health Service grants Am-13732 and AA-00196.

\section{REFERENCES}

1. Schweigert, B. S. 1948. Folic acid metabolism studies. III. Intravenous administration of pteroylglutamic acid and pteroyltriglutamic acid. J. Lab. Clin. Med. 33: 1271-1275.

2. Chanarin, I., D. L. Mollin, and B. B. Anderson. 1958. The clearance from the plasma of folic acid injected intravenously in normals and subjects with megaloblastic anaemia. Br. J. Haematol. 4: 435-446.

3. Chanarin, I., and M. Bennett. 1962. The disposal of small doses of intravenously injected folic acid. Br.J. Haematol. 8: 28-35.

4. Baker, H., O. Frank, S. Feingold, H. Ziffer, R. A. Gellene, C. M. Leevy, and H. Sobotka. 1965. The fate of orally and parenterally administered folates. Am. J. Clin. Nutr. 17: 88-95.

5. Herbert, V., and R. Zalusky. 1962. Interrelations of vitamin $B_{12}$ and folic acid metabolism: folic acid clearance studies. J. Clin. Invest. 41: 1263-1276.

6. Neal, G. E., and D. C. Williams. 1965. The fate of intravenously injected folate in rats. Biochem. Pharmacol. 14: 903-914.

7. John, D. G., S. Sperti, and A. S. V. Burgen. 1961. The metabolism of tritiated folic acid in man.J. Clin. Invest. 40: $1684-1695$.

8. Yoshino, T. 1968. The clinical and experimental studies on the metabolism of folic acid using tritiated folic acid III. Plasma clearance in man and organ distribution in rat following intravenous administration of tritiated folic acid. J. Vitaminol. (Kyoto). 14: 49-66.

9. Chanarin, I., and J. Perry. 1968. Metabolism of 5-methyl tetrahydrofolate in pernicious anaemia. $\mathrm{Br}$. J. Haematol. 14: 297-301.

10. Lane, F., P. Goff, R. McGuffin, E. R. Eichner, and R. S. Hillman. 1976. Folic acid metabolism in normal, folate deficient and alcoholic man. Br. J. Haematol. 34: 489501.

11. Whitehead, V. M., R. Pratt, A. Viallet, and B. A. Cooper. 1972. Intestinal conversion of folic acid to 5-methyl tetrahydrofolate in man. Br. J. Haematol. 22: 63-72.

12. Strum, W., P. F. Nixon, J. B. Bertino, and H. J. Binder. 1971. Intestinal folate absorption. I. 5-methyltetradydrofolic acid. J. Clin. Invest. 50: 1910-1916.

13. Olinger, E. J., J. R. Bertino, and H. J. Binder. 1973. Intestinal folate absorption. II. Conversion and retention of pteroylmonoglutamate by jejunum. J. Clin. Invest. 52: 2138-2145.

14. Perry, J., and I. Chanarin. 1970. Intestinal absorption of reduced folate compounds in man. Br. J. Haematol. 18: 329-339.

15. Corrocher, R., B. K. Bhuyan, and A. V. Hoffbrand. 1972. Composition of pteroylpolyglutamates (conjugated folates) in guinea-pig liver and their formation from folic acid. Clin. Sci. (Oxf.). 43: 799-813.

16. Shin, Y. S., M. A. Williams, and E. L. R. Stokstad. 1972. Identification of folic acid compounds in rat liver. Biochem. Biophys. Res. Commun. 47: 35-43.

17. Whitehead, V. M. 1973. Polygammaglutamyl metabolites of folic acid in human liver. Lancet. I: 743-745.
18. Houlihan, C. M., and J. M. Scott. 1972. The identification of pteroylpentaglutamate as the major folate derivative in rat liver and the demonstration of its biosynthesis from exogenous $\left({ }^{3} \mathrm{H}\right)$ pterolyglutamate. Biochem. Biophys. Res. Commun. 48: 1675-.1681.

19. Hillman, R. S., R. McGuffin, and C. Campbell. 1977. Alcohol interference with the folate enterohepatic cycle. Trans. Ass. Amer. Physicians. 90: 145-156.

20. Pratt, R. F., and B. A. Cooper. 1971. Folates in plasma and bile of man after feeding folic acid- ${ }^{3} \mathrm{H}$ and 5-formyltetrahydrofolate (folinic acid). J. Clin. Invest. 50: 455-462.

21. Lavoie, A., and B. A. Cooper. 1974. Rapid transfer of folic acid from blood to bile in man and its conversion into folate coenzymes and into a pteroylglutamate with little biological activity. Clin. Sci. Mol. Med. 46: 729-741.

22. Herbert, V. 1966. Aseptic addition method for lactobacillus casei assay of folate activity in human serum. J. Clin. Pathol. (Lond.). 19: 12-16.

23. Thenen, S. W., Y. S. Shin, and E. L. R. Stokstad. 1973. The turnover of rat-liver folate pools. Proc. Soc. Exp. Biol. Med. 142: 638-641.

24. Lavoie, A., E. Tripp, K. Parsa, and A. V. Hoffbrand. 1975. Polyglutamate forms of folate in resting and proliferating mammalian tissues. Clin. Sci. Mol. Med. 48: 67-73.

25. Rubinoff, M., R. Abramson, C. Schreiber, and S. Waxman. 1977. Differences in folate transport and distribution caused by folate binding protein (FABP). Clin. Res. 25: 317A. (Abstr.)

26. Rader, J. I., D. Miethammer, and F. M. Heunnekens. 1974. Effects of sulfhydryl inhibitors upon the transport of folate compounds into L1210 cells. Biochem. Pharmacol. 52: 2057-2059.

27. Corrocher, R., B. K. Bhuyan, and A. V. Hoffbrand. 1972. Composition of pteroylpolyglutamates (conjugated folates) in guinea-pig liver and their formation from folic acid. Clin. Sci. (Oxf.). 43: 799-813.

28. Hoffbrand, A. V., E. Tripp, and A. Lavoie. 1976. Synthesis of folate polyglutamates in human cells. Clin. Sci. Mol. Med. 50: 61-68.

29. Griffin, M. J., and G. M. Brown. 1964. The biosynthesis of folic acid. III. Enzymatic formation of dihydrofolic acid from dihydropteroic acid and of tetrahydropteroylpolyglutamic acid compound from tetrahydrofolic acid. J. Biol. Chem. 239: 310-316.

30. d'Urso-Scott, M., and D. R. Makulu. 1973. Biosynthesis of folate polyglutamates in rat liver slices. Fed. Proc. 32: 471 A. (Abstr.)

31. McGuffin, R., P. Goff, and R. S. Hillman. 1975. The effect of diet and alcohol on the development of folate deficiency in the rat. Br. J. Haematol. 31: 185-19225.

32. Kutzbach, C., E. Galloway, and E. L. R. Stokstad. 1966. Influence of vitamin $B_{12}$ and methionine on levels of folic acid compounds and folate enzymes in rat liver. Proc. Soc. Exp. Biol. Med. 124: 801-805.

33. Gawthorne, J. M., and E. L. R. Stokstad. 1970. The effect of vitamin $B_{12}$ and methionine on folic acid uptake by rat liver Proc. Soc. Exp. Biol. Med. 136: 42-46.

34. Smith, R. M., and W. S. Osborne-White. 1973. Folic acid metabolism in vitamin $B_{12}$-delficient sheep. Depletion of liver folates. Biochem. J. 136: 279-293.

35. Bertino, J. R., B. Simmons, and D. M. Donohue. 1964. Levels of dihydrofolate reductase and the formateactivating enzyme activities in guinea pig tissues before and after amethopterin administration. Biochem. Pharmacol. 13: 225-233.

36. Braganca, B. M., and U. W. Kenkare. 1964. Folic acid reductases in relation to normal and malignant growth. Acta Unio Int. Contra Cancrum. 8: 980-982. 